\title{
A Rare Case of Oral Myiasis Caused by Lucilia sericata in an Intubated Patient from Southeast Turkey
}

\author{
Türkiye’nin Güneydoğusunda Entübe Hastada Lucilia sericata’nın Neden \\ Olduğu Nadir Bir Oral Miyazis Olgusu
}

(1) Nihat Laçin ${ }^{1}$, (1) Mustafa Yalçın²

${ }^{1}$ Izmir Katip Celebi University Faculty of Dentistry, Department of Oral and Maxillofacial Surgery, Izmir, Turkey ${ }^{2}$ Istanbul Kent University Faculty of Dentistry, Department of Oral and Maxillofacial Surgery, Istanbul, Turkey

Cite this article as: Laçin N, Yalçın M. A Rare Case of Oral Myiasis Caused by Lucilia sericata in an Intubated Patient from Southeast Turkey. Turkiye Parazitol Derg 2021;45(4):326-28.

\begin{abstract}
The infestation of human and animal tissues or organs by the larvae of flies is collectively termed as myiasis. The occurrence of oral myiasis is analogously low compared with cutaneous myiasis as oral tissues are not habitually exposed to the external environment. Oral myiasis predominantly affects the periodontium, buccal and/or palatal mucosa, lips, and tongue. The prevalence of myiasis is substantially higher in tropical and subtropical regions, especially in developing countries. This research adduces a case of oral myiasis related to palatal gingiva in a young boy who was intubated due to pneumonia.
\end{abstract}

Keywords: Oral myiasis, Lucilia sericata, intubated patient

öz

Miyazis, insanların ve hayvanların doku ve organlarının sinek larvaları tarafından istila edilmesi anlamına gelmektedir. Ağız dokusu kalıcı olarak dış ortama maruz kalmadığından, oral miyazis insidansı kutanöz miyazise göre nispeten daha azdır. Oral miyazis en çok periodonsiyumu, bukkal ve/veya damak mukozasını, dudakları ve dili etkiler. Miyazis insidansı özellikle gelişmekte olan ülkelerde, tropikal ve subtropikal bölgelerde daha yüksektir. Burada, pnömoni nedeniyle entübe edilen küçük bir erkek çocukta damak diş etine bağlı bir oral miyazis olgusu sunulmuştur.

Anahtar Kelimeler: Oral miyazis, Lucilia sericata, entübe hasta

\section{INTRODUCTION}

The term myiasis is the infestation of tissues and organs of humans and animals by the larvae of flies (1). The entomologist Frederick Hope defined the myiasis in the human body (2). Human myiasis is usually seen in intact or damaged skin, but it can also be observed in the ears, nose, eyes, paranasal sinuses, lymph nodes, anus, vagina, and oral cavity $(3,4)$. Incidence of oral myiasis can be seen seldomly due to the oral tissues are not permanently damaged and related to the external environment (5). It mostly affects periodontium, buccal and/or palatal mucosa, lips and tongue (6). Oral myiasis is mostly seen in humid and warm regions especially in developing countries (3). There are a variety of predisposing factors such as low socio- economic status, malnutrition, drug use, alcoholism, low oral hygiene, facial trauma, open wound, mouthbreathers, mental retardation, senility and medical comorbidities (3). Thirteen fly species were described as a cause of oral myiasis (7). Dos Passos et al. (7) reported that the most frequent species are and Musca domestica.There are no standard guidelines for management of oral myiasis. Types of treatment for oral myiasis are removal of larvae with or without topical application of substances such as ether, chloroform, olive oil, iodoform to force the larvae out (8). The use of ivermectin, a macrolide antibiotic was effective in control of oral myiasis (9). We present a case of oral myiasis related to palatal gingiva in a young boy who was intubated due to pneumonia. 


\section{CASE REPORT}

A 9-year-old boy was referred to our clinic with a chief of complaint of larvae coming out his mouth. In the medical history, it was found out that the patient was intubated for 14 days due to pneumonia. The mouth of the patient was opened position due to intubation and the oral hygiene was also poor. In intraoral examination, deep periodontal pocket and caries was present in the maxillary incisors (Figure 1). Three maggots were detected in the gingival sulcus of palatal region of central incisors (Figure 2). The maggots were removed and gingival sulcus was irrigated. The patient was instructed to use antibiotics and analgesics. On entomological examination, species Lucilia sericata were described (Figures 3,4). The maggots were defined as Lucilia sericata by using light and scanning electron microscopes. The surface of $L$. sericata was coated with tiny short spines which were arranged in distinct bands around the body (10).

\section{DISCUSSION}

Myiasis is generally observed in rural areas and predisposing factors include medical conditions mental retardation, patients

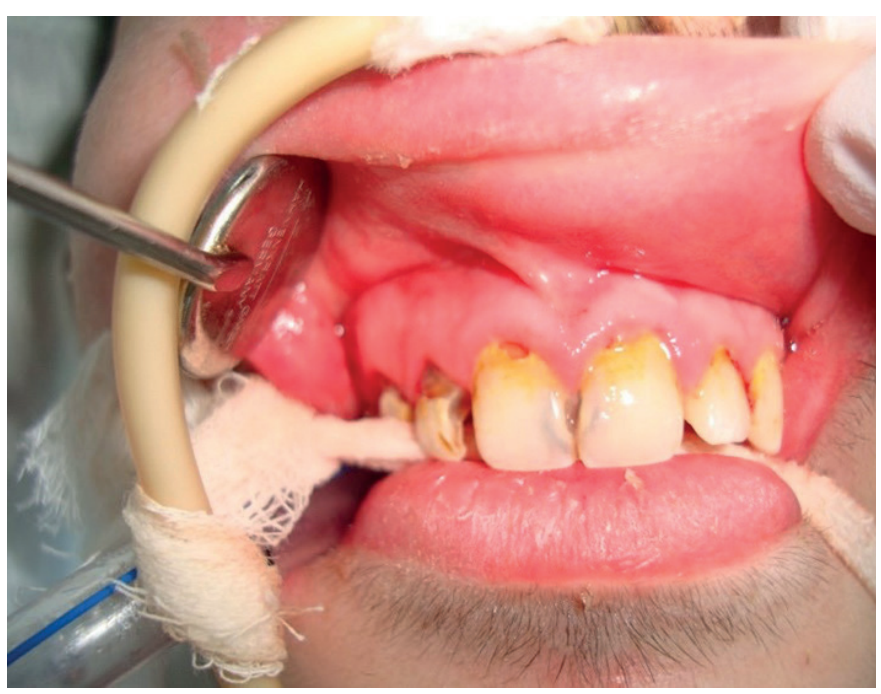

Figure 1. In intraoral examination, it can be seen that the patient had a poor oral hygiene

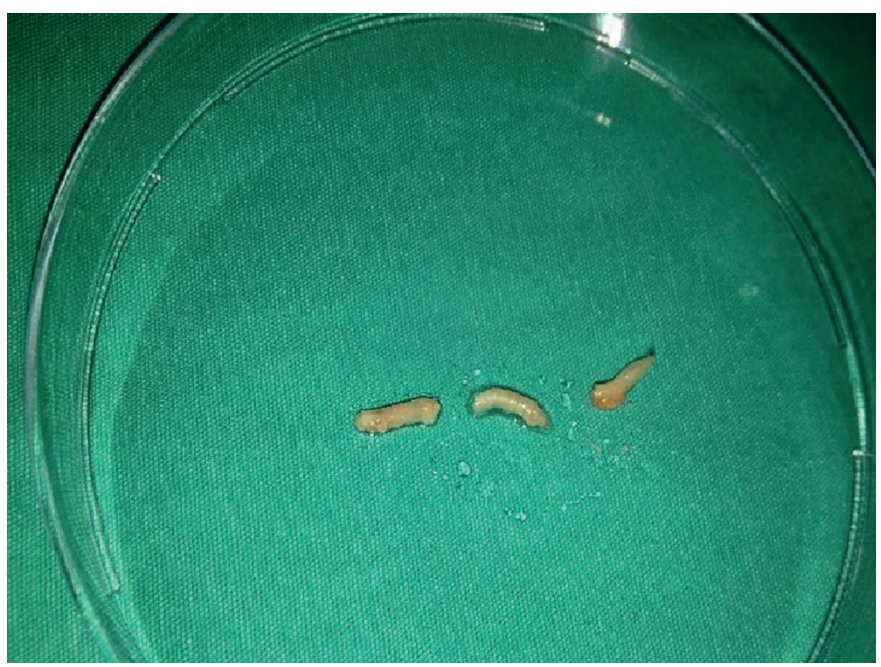

Figure 2. Three maggots are removed from periodontal pocket of palatal region of maxillary incisors with an open wound, mouth-breathers and drunkards (11). Myiasis might be subdivided into primary and secondary. Primary myiasis arises from biophagous larvae) and it is also known as obligatory myiasis. Secondary myiasis arises from the necrobiophagous larvae and it is also known facultative myiasis (12).

In Turkey, Taş Cengiz et al. (13) stated a case of oral myiasis in which five larvae of the family Calliphoridae were located in the maxillary gingiva causing a mild hemorrhage. Additional cases of oral myiasis were stated in the country caused by the species $W$. magnifica, Sarcophaga spp., H. bovis, and Calliphora spp. (14-17). The main symptoms of these cases were gingival lesion, edema, erythema, hemorrhage, lip swelling, and xerostomia (14-17). Arslan et al. (18) reported an oral myiasis in a child in whom 20 maggots were located in the maxillary gingiva and caused edema and erythema.

Dos Passos et al. (7) reported a literature review related to oral myiasis and one of the fly species in oral myiasis was L sericata. This species is a metallic green fly generally called the greenbottle fly. It is a well-known causative agent of fly strike in sheep of the British Isles, South Africa, and New Zealand (19). In Korea, causative agents of human myiasis cases were frequently

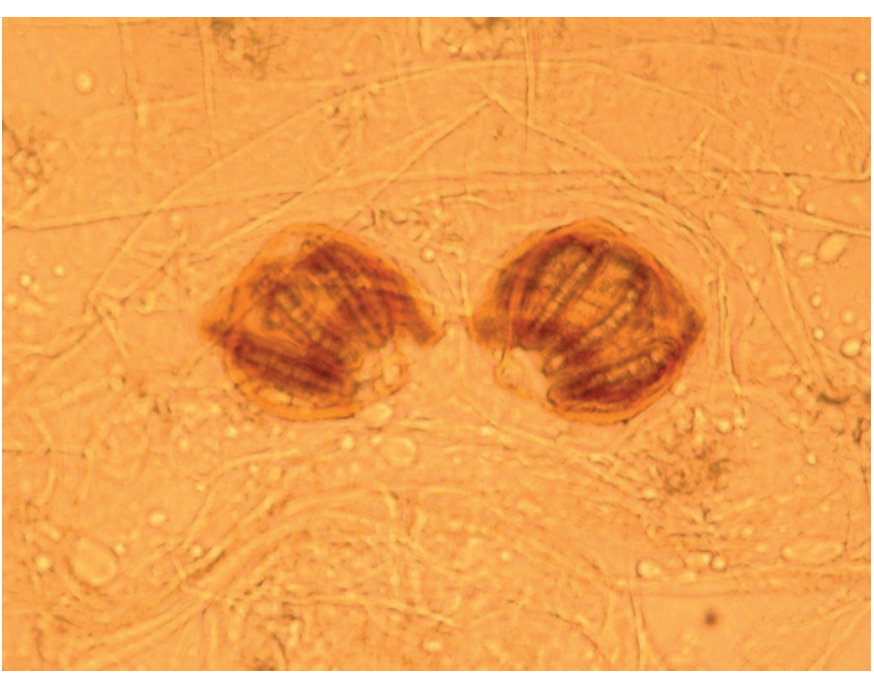

Figure 3. The posterior stigma of third instar larvae of Lucilia sericata

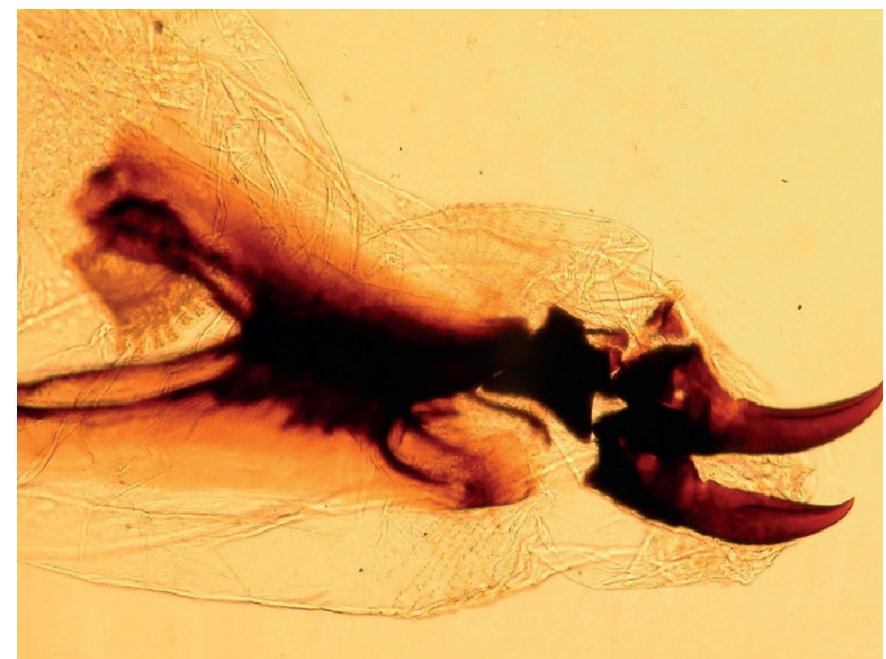

Figure 4. Photomicrograph revealing the cephalopharyngeal skeleton of the third instar larva of Lucilia sericata 
supposed as L. sericata or associated with the genus Lucilia, with the exception of a case involving Phormia spp. (20).

Severity of myiasis is related to location of infestation, lesions, and tissue inflammation. In our case, the lesion was located in the palatal area of maxillary central incisors, involving inoculation of the gingiva. There is no standard protocol for treatmant of oral myiasis, but many authors suggested that effective therapeutic choice is to eliminate all larvae and apply surgical debridement with or without asphyxiating substances $(7,21)$. The other treatment modalities are antibiotic theraphy, use of ivermectin and analgesics (22). It should be remembered that killing the larvae with any toxic substance/insecticide might have a negative effect, as those which are in the deeper layers of the tissue and are dead would decay and cause additional problems to the patient.

In the present case, we removed the maggots and performed the debridement and irrigation. Broad-specturum antibitotics and analgesic were prescribed.

\section{CONCLUSION}

Oral myiasis is an uncommon condition. It typically affects individuals with low socio-economic status, lack of hygiene habits, and comorbidities.

\section{* Ethics}

Informed Consent: As the patient was under the age of 18 consent form was taken from his parents.

Peer-review: Internally peer-reviewed.

\section{* Authorship Contributions}

Surgical and Medical Practices: N.L., Concept: N.L., Design: N.L., Data Collection or Processing: M.Y., Analysis or Interpretation: N.L., M.Y., Literature Search: M.Y., Writing: M.Y.

Conflict of Interest: No conflict of interest was declared by the authors.

Financial Disclosure: The authors declared that this study received no financial support.

\section{REFERENCES}

1. Droma EB, Wilamowski A, Schnur H, Yarom N, Scheuer E, Schwartz E. Oral myiasis: a case report and literature review. Oral Surg Oral Med Oral Pathol Oral Radiol Endod 2007; 103: 92-6.

2. Hope FW. On insects and their larvae occasionally found in human body. Trans R Soc Entomol 1840; 2: 256-71.

3. Saravanan T, Mohan MA, Thinakaran M, Ahammed S. Oral myiasis. Indian J Palliat Care 2015; 21: 92-4.
4. de Arruda JAA, de Oliveira Silva LV, Silva PUJ, de Figueiredo EL, Callou G, Mesquita RA, et al. Head and neck myiasis: a case series and review of the literature. Oral Surg Oral Med Oral Pathol Oral Radiol 2017; 124: e249-56.

5. Rossi-Schneider T, Cherubini K, Yurgel LS, Salum F, Figueiredo MA. Oral myiasis: a case report. J Oral Sci 2007; 49: 85-8.

6. Moriyama M, Kodama S, Suzuki M. Spontaneous temporomandibular joint herniation into the external auditory canal: a case report and review of the literature. Laryngoscope 2005; 115: 2174-7.

7. Dos Passos JBS, Coelho LV, de Arruda JAA, Silva LVO, do Valle IB, Santos MS, et al. Oral myiasis: Analysis of cases reported in the English literature from 1990 to 2020. Spec Care Dentist 2021; 41: 20-31.

8. Linhares AX. Mir'ases. In: Neves DP, Mello AL, Genaro O, et al, eds. Parasitologia Humana. 10th ed. Sa o Paulo, Brazil: Atheneu; 2001: 35065.

9. Marques-Silva L, Roy A, Araújo F, Serra-Negra JM, Gomez RS, Guimarães AL. Oral myiasis. Indian J Pediatr 2013; 80: 976-7.

10. Jang M, Ryu SM, Kwon SC, Ha JO, Kim YH, Kim DH, et al. A case of oral myiasis caused by Lucilia sericata (Diptera: Calliphoridae) in Korea. Korean J Parasitol 2013; 51: 119-23.

11. Rao GS, Chatra L, Prashanth SK. Oral myiasis: a rare entity. J Maxillofac Oral Surg 2009; 8: 398-400.

12. Reddy MH, Das N, Vivekananda MR. Oral myiasis in children. Contemp Clin Dent 2012; 3(Suppl 1): S19-22.

13. Taş Cengiz Z, Yılmaz H, Beyhan YE, Yakan Ü, Ekici A. An Oral Myiasis Case Caused by Diptera (Calliphoridae) Larvae in Turkey. Turkiye Parazitol Derg 2019; 43: 213-5.

14. Yazar S, Dik B, Yalçin S, Demirtaş F, Yaman O, Oztürk M, Sahin I. Nosocomial Oral Myiasis by Sarcophaga sp. in Turkey. Yonsei Med J 2005; 46: 431-4.

15. Çetın Özdemır E, Ekşi F, Şenyurt SZ, Üstün K, Karaoğlan İ, Ercıyas K. Wohlfahrtia magnifica'dan kaynaklanan gingival miyaz olgusu [A case of gingival myiasis caused by Wohlfahrtia magnifica]. Mikrobiyol Bul 2014; 48: 512-7.

16. Erol B, Unlü G, Balci K, Tanrikulu R. Oral myiasis caused by hypoderma bovis larvae in a child: a case report. J Oral Sci 2000; 42: 247-9.

17. Gursel M, Aldemir OS, Ozgur Z, Ataoglu T. A rare case of gingival myiasis caused by diptera (Calliphoridae). J Clin Periodontol 2002; 29: 777-80.

18. Arslan S, Islamoğlu A, Çobanoğlu B. A rare case of gingival myiasis in a 2-year-old child. Int J Paediatr Dent 2013; 23: 387-8.

19. James MT. The flies that cause myiasis in man. Washington DC, USA: US Government Printing Office; 1947. p.175.

20. Anderson GS, Huitson NR. Myiasis in pet animals in British Columbia: the potential of forensic entomology for determining duration of possible neglect. Can Vet J 2004; 45: 993-8.

21. Reddy MH, Das N, Vivekananda MR. Oral myiasis in children. Contemp Clin Dent 2012; 3(Suppl 1): S19-22.

22. Parwani RN, Patidar KA, Parwani SR, Wanjari SP. Exuberant Oral Myiasis Caused by Musca domestica (Housefly). J Glob Infect Dis 2014; 6: 35-8. 